\title{
AN INVESTIGATION OF BLOOD CHOLESTEROL LEVEL DURING STARVATION STRESS IN CLARIAS BATRACHUS
}

\author{
Nayan K. Prasad
}

\begin{abstract}
Cholesterol is an organic lipid molecule synthesized by all animal cells. It is an essential structural component of the cell membrane in all animals that is required to maintain both membrane structural integrity and fluidity. Cholesterol also serves as a precursor for the biosynthesis of steroid hormones, bile acids, and vitamin D. In the present investigation, the level of blood cholesterol has been estimated in both the sexes of Clariasbatrachus, which were subjected to starvation for 40 days. Cholesterol content was estimated by Sackett's Method (1925). Clariasbatrachus adapted well to starvation stress and survived all throughout the experimental period. The blood cholesterol concentration was higher in females than in males both under normal and starved conditions. After 10 days of starvation, the blood cholesterol dropped about 23 percent in male and about 21 percent in female. After 30 days of starvation, more than 70 percent drop was observed in male while it was only 55 percent in female. Similarly, after 40 days of starvation the males showed more decrease (88\%) than that of females (76\%). The bar notation of the recorded data showed that the drop between 0 and 10, 0 and 20, 0 and 30, 0 and 40 and among 10, 20, 30 and 40 days of starvation were highly significant at 1 percent of $P$ for blood cholesterol.
\end{abstract}

Key Words: Blood, cholesterol, clariasbatrachus, lipid, starvation.

\section{INTRODUCTION}

Starvation is the result of a severe or total lack of nutrients needed for the maintenance of life. It affects the normal metabolism of the body and prolonged starvation may even cause death of the animal. In fact, organism facing the starvation fights it till death at the cost of its own body-reserves. A decline in various body constituents of fish, following experimental starvation, have been reported by various authors. This paper deals with the results obtained for the freshwater catfish, Clariasbatrachus, following starvation up to 40 days.

The present study is aimed at finding the facts and causes of starvation and their consequent impacts on animals. A number of similar

Mr. Prasad is Reader at Department of Zoology, R.R.M. Campus, T.U., Janakpurdham, Dhanusha, Nepal 
studies have been carried out by many scholars in the past but most of them have been confined to mammalian fauna. In Nepal, very little work has been carried out to study the starvation-induced effects in fishes. So, it is pertinent to see and reveal the effect of starvation on fish as there is a unique feature of fish to withstand prolonged starvation through physiological and biochemical changes (Mustafa, 1983). In fact, starvation affects the physiological status and biochemical constituents of fish (Rajyasree and Naidu, 1989; Mukhopadhyaya et al., 1991; and Tripathi and Verma, 2003).

In the light of above fact, the present study has been designed to know the level of cholesterol content of blood in Clariasbatrachus during prolonged period of starvation of 40 days starting from 0 day to 40 days by estimating cholesterol constituents at an interval of 10 days.

\section{MATERIAL AND METHODS}

For the present investigation, healthy live fish were collected from a local fish pond with the help of fishermen. The fish were brought to the laboratory in large earthen pots covered with mosquito net. They were identified according to the parameters by Shrestha (1981) and were treated with $0.1 \% \mathrm{KMnO}_{4}$ solution for five minutes to get rid of any dermal infection. Healthy fish of an average length (18.8 $\mathrm{cm})$ and weight $(34.4 \mathrm{~g})$ were transferred one by one with the help of small hand net to a large glass aquarium of about 110 litres capacity measuring about $75 \mathrm{~cm} \times 30 \mathrm{~cm} \times 45 \mathrm{~cm}$ in size. They were allowed to acclimatize under laboratory condition for 20 days. During this period, the fish were fed twice a day with the commercial fish food to avoid their starvation. The water used was tap water containing $\mathrm{pH} 7.2$, dissolved oxygen $7.5 \mathrm{ppm}$, free carbon dioxide $12.4 \mathrm{ppm}$ and total alkalinity $112 \mathrm{ppm}$. Twenty four hours before starting the experiment, the food was stopped to clear off the alimentary canal. The study was carried out from May 2009 to June 2013. Biochemical estimations were made by taking the samples from each sex of acclimatized and well fed fish and the values obtained were taken as normal value for $C$. batrachus. A control group was kept in tap water. The remaining fishes were divided into four batches - A, B, C and D keeping 10 fishes each (5 males and 5 females). The fishes of batch A were kept without food at room temperature for 10 days, that of batch B for 20 days, $\mathrm{C}$ for 30 days and $\mathrm{D}$ for 40 days.

Starting from 0 day up to 40 days, the blood samples were collected from the starved fish. The blood was drawn from the cauda dorsal is with the help of a plastic syringe. EDTA was used as an anticoagulant. Blood cholesterol was estimated by Sackett's Method (1925) which is the modification of Bloor's method (1916). 


\section{OBSERVATION}

The value of blood cholesterol $(\mathrm{mg} / 100 \mathrm{ml})$ during different period of starvation in Clariasbatrachus has been shown in the table-1. The blood cholesterol concentration was higher in females than in males both under normal and starved conditions.

Table 1: Blood cholesterol (mg/100 ml) of Clariasbatrachus during different period of starvation:

\begin{tabular}{|l|c|c|c|c|c|}
\hline \multirow{2}{*}{ Sex } & \multicolumn{5}{|c|}{ Days of Starvation } \\
\cline { 2 - 6 } & $\mathbf{0}$ & $\mathbf{1 0}$ & $\mathbf{2 0}$ & $\mathbf{3 0}$ & $\mathbf{4 0}$ \\
\hline \multirow{2}{*}{ Male } & 407.29 & $312.74^{* *}$ & $204.74^{* *}$ & $112.99^{* *}$ & $48.70^{* *}$ \\
& \pm 2.92 & \pm 4.16 & \pm 2.94 & \pm 3.98 & \pm 1.61 \\
\hline \multirow{2}{*}{ Female } & 428.34 & $336.77^{* *}$ & $270.50^{* *}$ & $189.39^{* *}$ & $101.53^{* *}$ \\
& \pm 1.09 & \pm 1.36 & \pm 1.36 & \pm 1.16 & \pm 1.34 \\
\hline
\end{tabular}

Values are the mean of eight samples of both male and female $\pm \mathrm{SE}$

** Significant

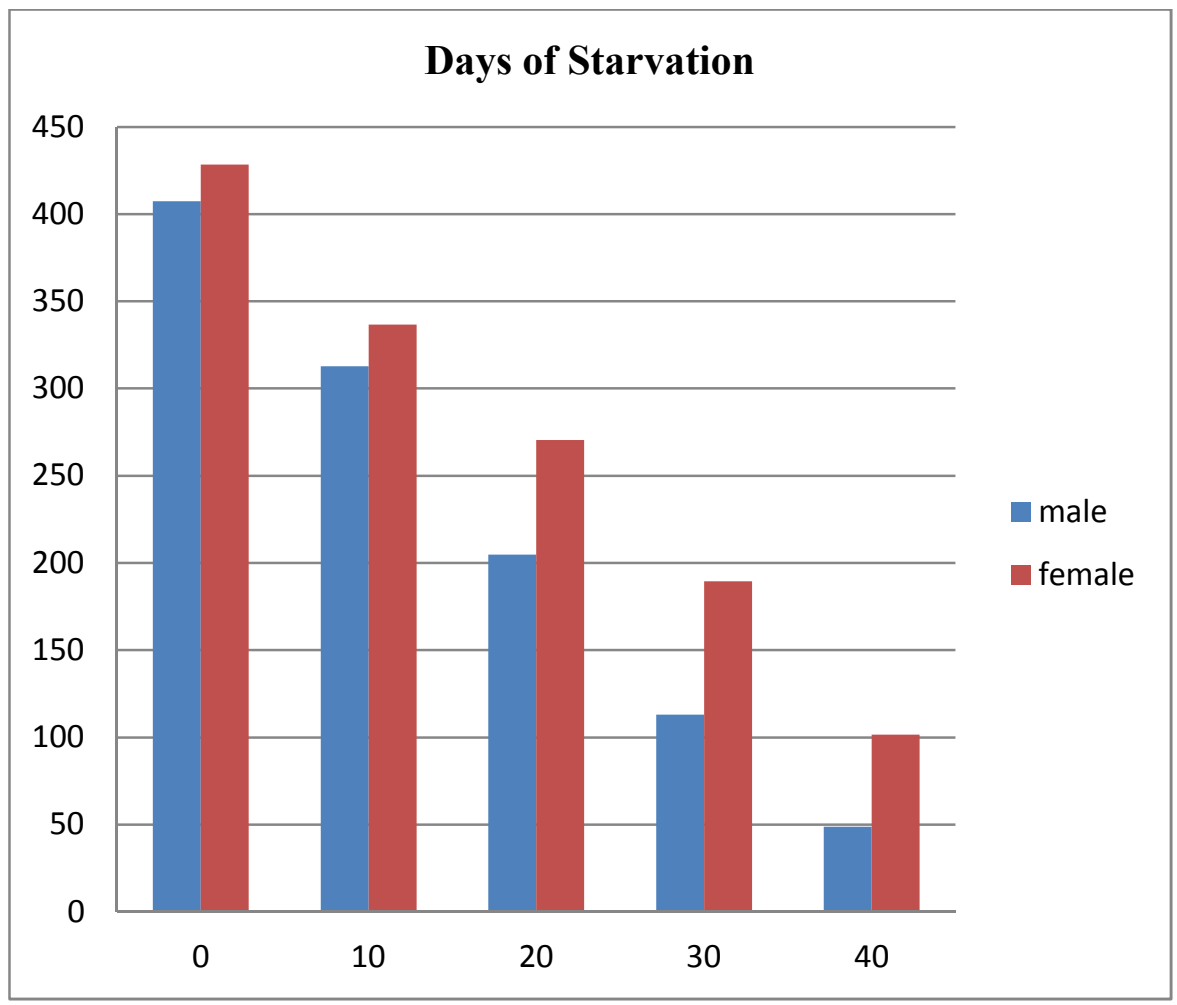

Figure 1: Effect of Starvation on blood cholesterol level in Clariasbatrachus. 


\section{RESULTS}

The starvation caused gradual and significant depletion in the blood cholesterol level. After 10 days of starvation, the blood cholesterol dropped about $23 \%$ in male and about $21 \%$ in female. After 30 days of starvation, more than $70 \%$ drop was observed in male while it was only $55 \%$ in female. Similarly, after 40 days of starvation the males showed more decrease $(88 \%)$ than that of females $(76 \%)$.

The bar notation of the recorded data showed that the drop between 0 and 10, 0 and 20, 0 and 30, 0 and 40 and among 10,20,30 and 40 days of starvation were highly significant at $1 \%$ of $\mathrm{P}$ for blood cholesterol.

\section{DISCUSSION}

Cholesterol is a very important member of the sterol class of lipids. It is present in all cells both in the cell membrane and cytoplasm. All body fluids contain cholesterol except cerebrospinal fluid (Bell et al., 1976) in which the amount is negligible. The amount of cholesterol in any tissue is roughly proportional to their degree of activity (Chatterjee, 1980).

Effect of prolonged as well as short term starvation has been extensively studied, mostly on temperate fish. During starvation carbohydrate stores are utilized first to yield energy and when these fall below the critical value, lipids are mobilized. Cholesterol is utilized very economically at least in the brain (Bell et al., 1976). During the breakdown of alcohol, the lipid is converted into glucose (Chatterjee, 1980). Depletion in the cholesterol content during starvation has been observed by various workers such as Idler et al. (1958), Shreni (1979), and Hallberg and Andersson (1984).

In the present investigation sharp and significant depletion in the cholesterol content was observed following starvation. The catabolism of the cholesterol is under the influence of ACTH and thyroid hormone as the injection of ACTH and hyperthyroidism reduces the cholesterol content in the solid tissues and blood (Chatterjee, 1980). Aubry et al. (1982), Mueller et al. (1982), and Tang et al. (1983) observed variation in the secretion of thyroid and corticoids in starving animals. The present observations regarding the depletion of cholesterol level following starvation are in conformity with the findings of Idler et al. (1959), and Shreni (1979). The sex difference of cholesterol content is in conformity with the observations of Shreni (1979).

Greene (1919), and Olley (1965) observed fall in the total lipid in Oncorhyncustschawvtscha and; Wilkins (1967) in Clupesharengus. Lovern (1934) reported selective drop of the highly unsaturated lipids when stores are being utilized. He further observed that depletion is more marked in males than in females. Wilkins (1967) showed that a 
reduction in the proportion of lipid in Clupesharengus during starvation coincided with a reduction in certain protein fractions. Blood cholesterol fluctuations was observed under different stress including starvation by several workers such as Siddiqui (1975), and Bano and Hameed (1978).

\section{CONCLUSION}

From this study, it is evident that when Clarias was subjected to starvation stress, the animal successfully overcame the stressful period and survived all through the starvation, by mobilizing energy reserves such as glycogen, proteins and lipids, to combat the stress.

The results showed that the response to starvation stress was specific for blood in both the sexes of Clariasbatrachus. The level of blood cholesterol was higher in females than in males both in normal as well as in starved conditions.

\section{ACKNOWLEDGEMENT}

The author renders his heartfelt gratitude to Dr. R.P. Sinha, and Dr. A.K. Verma, Professors, Department of Zoology, C.M. Science College, LNMU, Darbhanga, for their generous and constant guidance as well as for providing lab facilities during the research work.

\section{WORKS CITED}

Aubry, C.K. Bachmann and A. Burger (1982). "Effect of Thyroid Hormones and Starvation on Hepatic Nuclear Globulins in the Rat." Experenta. 38(6): 721.

Bell, G.H., D.E. Smith and C.R. Paterson (1976). Text Book of Physiology and Biochemistry. 9th edition, Edinburgh: E.L.B.S. and Churchill Livingstone.

Bano,Y. and T.Hameed (1979). "Seasonal Changes in Cholesterol Content of the Muscle of the Catfish-Clariasbatrachus (L). Indian J. Exp. Biol. 17(2): 214-5.

Bloor, W.R. (1916). "The Determination of Cholesterol in Blood." J. Biol. Chem. 24: 227-231.

Chatterjee, C.C. (1980). Human Physiology. Vol. 1, Calcutta: M.A.A.

Greene, C. W. (1919). "Biochemical Changes in the Tissues of King Salmon during the Fast of Spawning Migration." J. Biol. Chem. 39: 435-456.

Hallberg, A. and A. Anderson (1984). "Effects of Starvation on Phospholipid Metabolism of Pancreatic Islets." Diabetes Res. 1:105-110. 
Idler, D.R. and I. Bitners (1958). "Biochemical Studies on Sockeyes Salmon during Spawning Migration, Cholesterol, fat, Proteins and Water." Can. J. Boichem. Physiol. 36:793-798.

Lovern, J.A. (1934). "Fat Metabolism in Fish: Mobilization of Fat in Salmon."Biochem. J. 28: 1955-1960.

Mueller, M.J. ,U. Paschanand H.J. Saitz (1982). "Role of Thyroid Hormones in the Metabolic Adaptation to Starvation in the Miniature Pig." Acta Endocrinnol. Supl. 99: 76-77.

Mukhopadhyaya, P.K., S.N. Mohanty, K.M. Das, S. Sarkar and B.C. Batra (1991). "Growth and Changes in Carcass Composition in Young of Labeorohita and Cirrhinusmrigala during Feeding and Starvation." In: Fish Nutrition Research in Asia, Proceedings of the 4th Asian Fish Nutrition Workshop. Asian Fish Society, 5: 87-91.

Mustafa, S. (1983). Changes in Biochemical Composition in Starving Catfish Heteropneustesfossilis." Japanese Journal of Ichthyology. 29(4): 416-420.

Olley, J. and W.R.H. Duncan (1965). "Lipids and Protein Determination in Fish Muscle Fish."Journal of the Science of Food and Agriculture. 16(2): 99-104.

Rajyasree, M. and K.R.P. Naidu (1989). "Starvation Induced Changes in Biochemical Aspects of Hepatic Tissue offish, Labeorohita." Indian J. Fish. 36: 339-341.

Sackett, G.E. (1925). "Modification of Bloor's Method for the Determination of Cholesterol in Whole Blood or Blood Serum." $J$. Biol. Chem. 64: 203-205.

Shreni, D.K. (1979). "Influence of Starvation on the Brain and Liver Cholesterol Levels of Catfish, Heteropneustusfossilis (Bloch)." Proc. Animal Sci. 88(3): 205-208.

Shrestha, J. (1981). Fishes of Nepal. First ed., Kathmandu: Curriculum Development Centre, T.U.

Siddiqui, N. (1975). "Variation in Chemical Constituents of Bloodplasma of Clariasbatrachus(L) during Starvation." Curr. Sci., 44: 126-127.

Tang, F., C.P. Lee and A.C.L. Hsieh (1983). "Synergistic Effects of Cold and Starvation on the Plasma Levels of Corticosterons in Male Rat." Acta Endocrinol. 103: 256-277.

Tripathi, G. and P. Verma (2003). Starvation-Induced Impairment of Metabolism in a Freshwater Catfish." Z. Naturforsch. 58c: $446-451$.

Wilkins, N.P. (1967). "Starvation of the Herring, Clupesharengus L.: Survival and Some Gross Biochemical Changes." Comp. Biochem. Physiol. 23: 503-518. 